Full length article

\title{
Genes related to cell-mediated cytotoxicity and interferon response are induced in the retina of European sea bass upon intravitreal infection with nodavirus
}

\author{
Yulema Valero $^{\mathrm{a}, \mathrm{b}}$, Bassima Boughlala ${ }^{\mathrm{c}}$, Marta Arizcun ${ }^{\mathrm{a}}$, Sonal Patel ${ }^{\mathrm{d}}$, Ingrid U. Fiksdal ${ }^{\mathrm{d}}$, \\ M. Ángeles Esteban ${ }^{\mathrm{e}}$, Joaquín De Juan ${ }^{\mathrm{c}}$, José Meseguer ${ }^{\mathrm{e}}$, Elena Chaves-Pozo ${ }^{\mathrm{a}}$, Alberto Cuesta ${ }^{\mathrm{e}, *}$ \\ a Centro Oceanográfico de Murcia, Instituto Español de Oceanografía (IEO), Carretera de la Azohía s/n, Puerto de Mazarrón, 30860, Murcia, Spain \\ b Grupo de Marcadores Inmunológicos, Laboratorio de Genética e Inmunología Molecular, Instituto de Biología, Pontificia Universidad Católica de Valparaíso, Valparaíso, \\ Chile \\ ${ }^{\mathrm{c}}$ Departamento de Biotecnología, Universidad de Alicante, Ctra. San Vicente-Alicante $s / n, 03080$, Alicante, Spain \\ ${ }^{\mathrm{d}}$ Diseases and Pathogen Transmission, Institute of Marine Research, Nordnesgaten 50, 5005, Bergen, Norway \\ e Fish Innate Immune System Group, Department of Cell Biology and Histology, Faculty of Biology, Campus Regional de Excelencia Internacional "Campus Mare Nostrum", \\ University of Murcia, 30100, Murcia, Spain
}

\section{A R T I C L E I N F O}

\section{Keywords:}

Nodavirus

European sea bass

Retina

Innate immune response

Adaptive immune response

Interferon

Cytotoxicity

\begin{abstract}
A B S T R A C T
Viral diseases are responsible for high rates of mortality and subsequent economic losses in modern aquaculture. The nervous necrosis virus (NNV) produces viral encephalopathy and retinopathy (VER), which affects the central nervous system, is considered one of the most serious viral diseases in marine aquaculture. Although some studies have localized NNV in the retina cells, none has dealt with immunity in the retina. Thus, for the first time, we intravitreally infected healthy specimens of European sea bass (Dicentrarchus labrax) with NNV with the aim of characterizing the immune response in the retina. Ultrastructural analysis detected important retinal injuries and structure degradation, including pycnosis, hydropic degeneration and vacuolization in some cell layers as well as myelin sheaths in the optic nerve fibres. Immunohistochemistry demonstrated that NNV replicated in the eyes. Regarding retinal immunity, NNV infection elicited the transcription of genes encoding proteins involved in the interferon (IFN) and cell-mediated cytotoxicity (CMC) responses as well as B and T cell markers, demonstrating that viral replication influences innate and adaptive responses. Further studies are needed to understand the retina immunity and whether the main retinal function, vision, is affected by nodavirus.
\end{abstract}

\section{Introduction}

Nodavirus (NNV) has become one of the most devastating marine fish viruses worldwide, and it represents a serious economic threat to aquaculture [1], affecting both marine and freshwater fish species [1-3]. The virus causes viral encephalopathy and retinopathy (VER), which is characterized by symptoms of neurological damage and high mortality rates of up to $100 \%$, especially in larvae and juvenile European sea bass (Dicentrarchus labrax), one of most susceptible species to the virus [4,5], which is extremely important in Mediterranean aquaculture. NNV is a bipartite, naked, icosahedral virus of $25-30 \mathrm{~nm}$, composed of 2 positive single-stranded RNA fragments, RNA1 and RNA2, which are capped but not polyadenylated. The capsid protein (CP) is encoded by the RNA2 and is involved in host specificity whilst
RNA1 codes for the non-structural protein RNA-dependent RNA polymerase (RdRp) [6,7]. In addition, a sub-genomic RNA1 transcript, RNA3, encodes the protein B2 which seems to be pivotal for virus accumulation since it antagonizes hosts siRNA and is only expressed in newly infected fish cells [8-10].

NNV infects cells from the brain, spinal cord and retina, causing extensive tissue degradation and altering their functioning [1]. The first evidence of retina damage was described several decades ago, when extensive vacuolation, especially in cells from the bipolar and ganglionic layers, was observed in a variety of fish species [11-14]. This injury to the retina structure is associated with the presence of NNV in the tissue and represents one of the key histopathological features of VER disease. For example, viral particles have been detected in the nuclear and ganglion cell layers and adjacent to the circumferential

\footnotetext{
* Corresponding author.

E-mail address: alcuesta@um.es (A. Cuesta).
} 
germinal zone at the ciliary margin close to the iris of Atlantic halibut (Hippoglossus hippoglossus) [15,16]. As in other fish species, retina cell damage in European sea bass was described in most layers from the outer limiting membrane to the ganglion layer, with viral particles observed in the nuclear region concomitantly with cell damage [17-19]. As an immune privileged site, the retina's regeneration process after impairment is difficult [20] and so any immune response after infection or injury might be regulated in a particular manner. Despite this, several studies have focused on the retinal detection of NNV and, although severe brain cell damage results in massive mortalities [1], no studies have been carried out to analyse the loss of eye function including the immune response.

This study is the first to address NNV colonization in the retina and the immune responses developed by the tissue, in order to elucidate whether the damage and immune responses might impair fish vision. Intravitreal infection of the right eye of juveniles of European sea bass triggered the massive infection in both retinas at 6 days. Cell damage was extensive in the retinal layers, optical centre and the medullary region of the retina enhancing the expression of genes related with interferon (IFN) and cell-mediated cytotoxicity (CMC) responses, as well as B and $\mathrm{T}$ lymphocytes probably leading to retina disfunction. However, further studies are needed to clarify whether vision is affected.

\section{Materials and methods}

\subsection{Animals}

Healthy juvenile specimens of European sea bass (Dicentrarchus labrax L.) were bred and kept at the Centro Oceanográfico de Murcia (IEO, Mazarrón, Murcia). The fish were kept in $14 \mathrm{~m}^{3}$ tanks with the natural sea water temperature, a flow-through circuit, a suitable system for aeration and filtration and a natural photoperiod. Fish were fed daily with $1 \%$ of their biomass with commercial pellets (Skretting). The environmental parameters and food intake were recorded daily. Fish with a mean body weight (bw) of $12.3 \pm 1.4 \mathrm{~g}$ were transported to the University of Murcia (Spain) aquaria to perform in vivo infections (see below). Fish were randomly divided into two tanks, kept in 450-500 1 running seawater ( $28 \%$ salinity) aquaria at $25^{\circ} \mathrm{C}$ with a $12 \mathrm{~h}$ light: $12 \mathrm{~h}$ dark photoperiod and acclimatised for 15 days prior to the onset of the experiments. Before sampling, all specimens were anesthetized with $40 \mu \mathrm{l} / 1$ of clove oil, completely bled and immediately decapitated and weighed. The experiments described comply with the Guidelines of the European Union Council (2010/63/UE). The protocol was approved by the Committee on the Ethics of Animal Experiments of the IEO (Permit Number: 2010/02) and of the University of Murcia (Permit Number: A13150104).

\subsection{Nodavirus stock}

NNV (strain It/411/96, genotype RGNNV) was propagated in the SSN-1 cells [21]. The SSN-1 cells were grown at $25^{\circ} \mathrm{C}$ in Leibovitz's L15medium (Gibco) supplemented with $10 \%$ foetal bovine serum (FBS; Gibco), $2 \mathrm{mM}$ L-glutamine (Gibco), $100 \mathrm{IU} / \mathrm{ml}$ penicillin (Gibco), $100 \mu \mathrm{g} / \mathrm{ml}$ streptomycin (Gibco) and $50 \mu \mathrm{g} / \mathrm{ml}$ gentamicin (Gibco) using Falcon Primaria cell culture flasks (Becton Dickinson). Inoculated cells were incubated at $25^{\circ} \mathrm{C}$ until the cytopathic effect (CPE) was extensive. Supernatants were harvested and centrifuged to eliminate cell debris. Virus stock was titrated in 96-well plates and expressed as the viral dilution infecting $50 \%$ of the cell cultures $\left(\mathrm{TCID}_{50}\right.$ ), following the methodology described previously [22], before being used in the experiments.

\subsection{Intravitreal infection}

Sedated fish with $20 \mu \mathrm{l} / 1$ of clove oil were infected by a single injection of $2 \mu \mathrm{l}$ of SSN-1 culture medium (mock-infected) or with culture medium containing a total dose of $10^{4} \mathrm{TCID}_{50} /$ fish of NNV in the right eye vitreous body, leaving the left eye free of injection. Fish ( $\mathrm{n}=6$ fish/group and time) were sampled at 1, 4, 24, 72 (3 days) and 144 ( 6 days) h after viral injection. Retinas were individually sampled and immediately frozen in TRIzol Reagent (Life Technologies) for later RNA isolation or placed into fixative solutions for microscopic examination.

\subsection{Immunohistochemistry}

Six days $(144 \mathrm{~h})$ post-injection, retinas ( $\mathrm{n}=4 \mathrm{fish} /$ group) from both eyes were fixed in Bouin's solution for $16 \mathrm{~h}$ at $4{ }^{\circ} \mathrm{C}$, embedded in paraffin (Paraplast Plus; Sherwood Medical) and sectioned at $3 \mu \mathrm{m}$. After dewaxing and rehydration, the sections were subjected to an indirect immmunohistochemical (IHC) process using two antibodies specific to: (i) the NNV capsid protein (anti-CP, Ø233 antibody) or (ii) the NNV B2 protein (anti-B2, Ø6073 antibody) at the optimal dilution of 1:500, as previously described [10]. In brief, the sections were incubated at $60{ }^{\circ} \mathrm{C}$ for $30 \mathrm{~min}$, dewaxed in xylene, rehydrated in a series of ethanol baths and washed in running water. Prior to staining the tissue sections were autoclaved for $15 \mathrm{~min}$ in $0.01 \mathrm{mM}$ citric acid ( $\mathrm{pH}$ 6.0) for antigen retrieval. To prevent non-specific antibody binding, sections were blocked by using $5 \%$ bovine serum albumin (BSA; Sigma) in Tris buffered saline (TBS, $0.05 \mathrm{M}, \mathrm{pH} 7.6$; Merck) for $20 \mathrm{~min}$. The primary antiB2 (Ø6073 antibody) or anti-CP (Ø233 antibody) sera were diluted in TBS containing $2.5 \% \mathrm{BSA}$ and incubated for $30 \mathrm{~min}$ at $37^{\circ} \mathrm{C}$, and then washed for $5 \mathrm{~min}$ with TBS. The Vectostain universal ABC-AP kit (Vector Laboratories), which provides both the secondary antibody (biotinylated anti-mouse/rabbit immunoglobulin) and avidin-biotin alkaline phosphatase (ABC-AP) was used. After TBS washes, the sections were incubated for $5 \mathrm{~min}$ with DAKO Fuchsin Substrate- and Cromogen system (Dako), followed by washing in running tap water before counterstaining with Shandon's haematoxylin and mounting in aqueous mounting medium (Aquatex, BDH laboratory). The specificity of the reaction was determined by using sections of tissue from control fish and by omitting the primary antibody on sections of tissue from infected fish.

\subsection{Transmission electron microscopy}

For transmission electron microscopy (TEM), the right eye retina was removed from the specimens and immersed in the fixative $(1 \%$ paraformaldehyde, $1.26 \%$ glutaraldehyde and $0.02 \% \mathrm{CaCl}_{2}$ in $0.1 \mathrm{M}$ phosphate buffer, $\mathrm{pH} 7.4$ ) at $4{ }^{\circ} \mathrm{C}$ overnight. After fixation, the retinas were post-fixed with $2 \% \mathrm{OsO}_{4}$ for $1 \mathrm{~h}$, dehydrated in ethanol, and embedded in Epon-812 (Polysciences) for TEM study. Semithin sections from each retina were observed and photographed with an Optic Microscope Leica DMRB. Thin sections of $70 \mathrm{~nm}$ were contrasted with uranyl acetate and lead citrate and observed in a Zeiss EM10C/CR electron microscope.

\subsection{Gene expression by real-time $q P C R$}

For the qPCR study, we only used the left eye retina in order to determine the effect of NNV and replication and avoid the local inflammation or leucocyte infiltration produced by the injection procedure in the right eye.

Total RNA was independently extracted from the left eye retina ( $n=6$ independent fish/group and time) with TRIzol Reagent (Life Technologies) following the manufacturer's instructions, and quantified with a spectrophotometer (Cecil Instruments Ltd). Isolated RNA was DNase I treated (amplification grade, 1 unit/ $\mu g$ RNA, Life Technologies) and the SuperScript III RNase $\mathrm{H}^{-}$Reverse Transcriptase (Life Technologies) was used to synthesize the first strand cDNA with $1 \mu \mathrm{l}$ of random hexamers $(0.25 \mu \mathrm{g} / \mu \mathrm{l}$; Life Technologies) from $1 \mu \mathrm{g}$ of total 
Table 1

Gene accession numbers and primer sequences used for gene expression analysis.

\begin{tabular}{|c|c|c|c|c|}
\hline & Protein name & Abbreviation & Accession number & Sequence $\left(5^{\prime} 3^{\prime}\right)$ \\
\hline \multirow[t]{4}{*}{ NNV } & Capsid protein & $c p$ & D38636 & CGTGTCAGTCATGTGTCGCT \\
\hline & & & & CGAGTCAACACGGGTGAAGA \\
\hline & RNA-dependent RNA polymerase & $r d r p$ & AF319555 & GTGTCCGGAGAGGTTAAGGATG \\
\hline & & & & CTTGAATTGATCAACGGTGAACA \\
\hline \multirow[t]{38}{*}{ European sea bass } & Type I interferon & ifn & AM765847 & GGCTCTACTGGATACGATGGC \\
\hline & & & & CTCCCATGATGCAGAGCTGTG \\
\hline & Interferon-induced GTP-binding protein $\mathrm{Mx}$ & $m x$ & AM228977, HQ237501, AY424961 & GAAGAAGGGCTACATGATCGTC \\
\hline & & & & CCGTCATTGTAGAGAGTGTGGA \\
\hline & Signal transducer and activator of transcription 1 & stat1 & DLAgn_00136580 & ACCGTCCGCTGTCTATTGACTA \\
\hline & & & & CAGATGCCCCAGCGAAACC \\
\hline & Interferon-stimulated gene 15 & isg15 & HG916840 & CGACATCATCCGCACCTACA \\
\hline & & & & AGGCCTTGTCTTTGGGGATG \\
\hline & Interferon gamma & ifng & KJ818329 & TCAAGATGCTGAGGCAACAC \\
\hline & & & & AGTGCTTTGCTCTGGACGAC \\
\hline & Complement component 3 & $c 3$ & HM563078 & ACCAAAGAACTGGCAACCAC \\
\hline & & & & CTAGCAGTCGGTCAGGGAAC \\
\hline & Hepcidin & hamp & DQ131605 & CCAGTCACTGAGGTGCAAGA \\
\hline & & & & GCTGTGACGCTTGTGTCTGT \\
\hline & Dicentracin & dic & AY303940 & GGCAAGTCCATCCACAAACT \\
\hline & & & & ATATTGCTCCGCTTGCTGAT \\
\hline & NK lysin & nklys & KY801205 & GAAGAAACACCTCGGGGAAT \\
\hline & & & & GCAGGTCCAACATCTCCTTC \\
\hline & Immunoglobulin mu heavy chain & ighm & FN908858 & AGGACAGGACTGCTGCTGTT \\
\hline & & & & CACCTGCTGTCTGCTGTTGT \\
\hline & T-cell receptor beta chain & $t c r b$ & FN687461 & GACGGACGAAGCTGCCCA \\
\hline & & & & TGGCAGCCTGTGTGATCTTCA \\
\hline & CD8 alpha & $c d 8 a$ & AJ846849 & CTGTCCTCCGCTCATACTGG \\
\hline & & & & TTGTAATGATGGGGGCATCT \\
\hline & CD4 & $c d 4$ & AM849812 & ATTCTTTGCTAAGCCAGGCG \\
\hline & & & & CATTGTCTTGGTCTGGCGTC \\
\hline & Granzyme A & gzma & KJ818347 & TCCCTGCTATGATGCAACTG \\
\hline & & & & ATTTCACCGTCTTGGTTTGC \\
\hline & Granzyme B & $g z m b$ & DLAgn_00225890 & ACATGTTGTACTTGGCACCCA \\
\hline & & & & CATGATGTCGTTACCTCGTCCT \\
\hline & Perforin & $p r f$ & KY801204 & CTGTACAACGGGCTTCTGGT \\
\hline & & & & ACTGGAGAACGTTGGACCAC \\
\hline & Elongation factor 1 alpha & ef1a & FM019753 & CGTTGGCTTCAACATCAAGA \\
\hline & & & & GAAGTTGTCTGCTCCCTTGG \\
\hline & Ribosomal protein L13 alpha & $l 13 a$ & DT044539 & GCGAAGGCATCAACATCTCC \\
\hline & & & & AGACGCACAATCTTGAGAGCAG \\
\hline & Tubulin alpha & tuba & AY326429 & ACGAGGCCATCTACGACATC \\
\hline & & & & GGCCGTTATGGACGAGACTA \\
\hline
\end{tabular}

RNA, at $50{ }^{\circ} \mathrm{C}$ for $60 \mathrm{~min}$.

With the aim of estimating the levels of NNV and immunity in the retina, the transcription of genes coding for the following proteins was analysed: (i) the NNV capsid protein $(c p)$ and RNA-dependent RNA polymerase ( $r d r p$ ); (ii) the type I IFN (ifn), the IFN-induced GTP-binding protein $(m x)$, signal transducer and activator of transcription 1 (stat1), interferon-stimulated gene 15 (isg15); (iii) the type II IFN gamma (ifng); (iv) antimicrobials such as complement component 3 (c3), hepcidin (hamp), dicentracin (dic) and Nk-lysin (nklys); (v) T cell marker tcrb as well as $c d 4$ and $c d 8 a$ for helper and cytotoxic T (CTL) cells, respectively; (vi) CMC mediators such as granzyme A ( $g z m a)$, granzyme B ( $g z m b)$ and perforin (prf); and (vii) B cell marker immunoglobulin $M$ heavy chain (ighm). For this, retina cDNA samples were analysed by real-time PCR using an ABI PRISM 7500 instrument and SYBR ${ }^{\circ}$ Green PCR Core Reagents (Applied Biosystems) as previously described [23]. The specific primers are shown in Table 1. For each individual mRNA sample, gene expression was corrected by the geometric average of the expression of three endogenous genes: elongation factor 1 alpha (ef1a), ribosomal protein L13 alpha (l13a) and tubulin alpha (tuba). Data are presented as $2^{-\Delta \mathrm{Ct}}$, where $\Delta \mathrm{Ct}$ is determined by subtracting the geometric average $\mathrm{Ct}$ value from the target $\mathrm{Ct}$. A melting curve analysis of the amplified products validated the primers for specificity. Negative controls with no template were always included in the reactions. Before the experiments, the specificity of each primer pair was studied using positive and negative samples.

\subsection{Calculations and statistical analysis}

All data are presented as mean \pm SEM. The t-Student test was used to determine statistical differences $(\mathrm{P}<0.05)$ between infected and control groups. One-way ANOVA and a Tukey post hoc test were applied to determine differences between sampling times. Statistical analyses were conducted using SPPS 20.0.

\section{Results}

Histological and PCR analyses of all control fish were negative for NNV RNA and any histopathological changes. However, fish receiving the intravitreal injection of NNV showed typical symptoms of VER disease such as erratic swimming, disorientation and changes of skin colour from day 5 and onwards [Supplementary data, videos S1 (control group) and S2 (infected group)]. No mortality was noticed until 6 days post infection.

Supplementary data related to this article can be found at http://dx. doi.org/10.1016/j.fsi.2018.01.034.

\subsection{Nodavirus infects and replicates in the retina and optical centre}

The transcriptional levels of the mRNA coding for the two main proteins of the virus, CP and the RdRp proteins, were studied in retina samples (Fig. 1, Supplementary table S1). Transcripts of $c p$ and $r d r p$ 


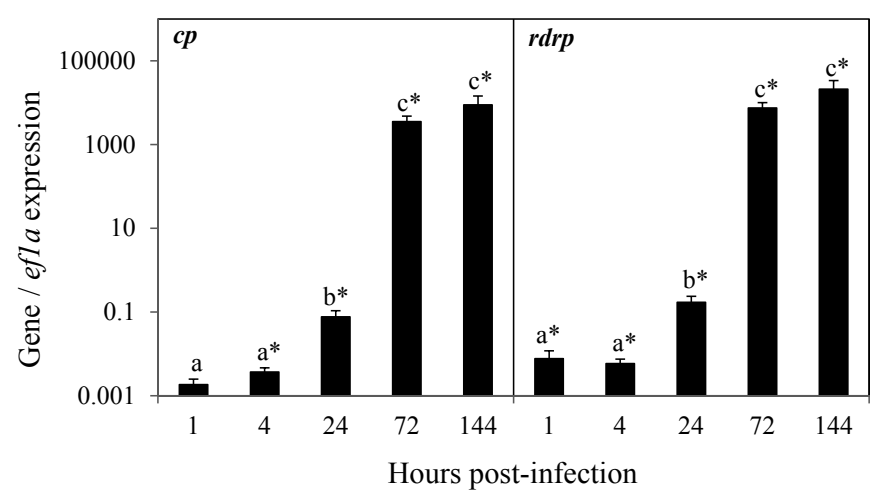

Fig. 1. Transcript levels of the NNV genes coding for capsid ( $c p$ ) and polymerase ( $r d r p$ ) proteins in European sea bass retina 1, 4, 24, 72 and $144 \mathrm{~h}$ after intravitreal infection with NNV. Data represent the mean \pm standard error of the mean (SEM; $n=6$ fish retina/ group and time). Significance level (P) was fixed at 0.05 . Asterisks represent statistical differences between control and infected (NNV) groups according to the t-Student test. Letters denote statistical differences between sampling times according to ANOVA and Tukey's comparison of means.

were detected in the left eye, which was not injected with NNV, from 4 and $1 \mathrm{~h}$ after NNV infection onwards, respectively, reaching maximum levels after $72 \mathrm{~h}$ (Fig. 1).

The presence of viral proteins in the retina was also tested by immunohistochemistry (IHC) in both eyes (Fig. 2). No IHC staining was evident in the negative controls (Fig. 2A,B,C), while in infected individuals, the viral $\mathrm{CP}$ protein was present in most of the retinal cell layers: the outer limiting membrane (OLM), outer nuclear layer (ONL), outer plexiform layer (OPL), inner nuclear layer (INL), inner plexiform layer (IPL) and ganglion layer (GL) (Fig. 2D). Positive staining was also evident in the optical centre and the medulla region (Fig. 2E and F), with the highest expression observed in cells from the inner nuclear layer (Fig. 2D) and the medullar region (Fig. 2F). Furthermore, the viral B2 protein was found in the cytoplasm of scarce cells of the outer nuclear layer, outer plexiform layer, inner nuclear layer, inner plexiform layer and ganglion layer (Fig. 2G), but also in some cells of the optic nerve (Fig. $2 \mathrm{H}$ ) and the medulla region (Fig. 2I). Alterations in the retinal structure included cell degradation in the outer nuclear and inner plexiform layers (Fig. 2D,G). Moreover, in the medullar region, typical histopathological features related to NNV infection, such as cell lysis and structure disorganization, were observed (Fig. 2F,I).

When the retina tissue was analysed for ultrastructural alterations by TEM, the most common cellular injuries provoked by NNV infection, previously described by light and electron microscopy, were observed (Fig. 3). The first sign of NNV infection was the emergence of scattered pycnotic nucleus in the outer nuclear layer after $24 \mathrm{~h}$ (Fig. 3A-C). Seventy-two $h$ post-infection, new changes were observed in the outer plexiform layer, including varying degrees of cone pedicle vacuolization, in the outer nuclear layer (Fig. 3D-F). A week after infection, the above-mentioned changes were less pronounced (Fig. 3G) and microglial infiltration of the granulocytes (Fig. $3 \mathrm{H}$ ) in the inner nuclear layer and optic centre layer (Fig. 3I) was evident.

\subsection{NNV induces transcription of IFN-related genes in the European sea bass retina}

Once it had been demonstrated that NNV infected and replicated in the retinas of both eyes and the optic centre, the type I and II IFN pathways were studied, analysing the expression pattern of ifn, stat1, isg15 and $m x$ (type I) or ifng (type II) genes (Fig. 4, Supplementary table S1). The results pointed to activation of the type I IFN pathway as seen by the intense up-regulation of the transcript levels of ifn, stat1, isg15 and/or $m x$ from $24 \mathrm{~h}$ onwards (Fig. 4A-D). By contrast, the transcription of stat 1 and $m x$ was down-regulated $1 \mathrm{~h}$ post-injection. For its part, the expression of ifng was undetectable in control group at any time point assayed and also in the infected group $1 \mathrm{~h}$ post-infection, whilst it was up-regulated in the infected group from $4 \mathrm{~h}$ onwards, reaching the highest levels $72 \mathrm{~h}$ post-infection (Fig. 4E).

\subsection{Expression of AMP genes in the retina was slightly altered by NNV}

As regards the AMP response against NNV, the results showed few alterations in genes coding for AMPs transcription (Fig. 5, Supplementary table S1). Thus, the expression of $c 3$ gene was not altered by NNV (Fig. 5A). Interestingly, hamp gene expression was strongly up-regulated $72 \mathrm{~h}$ post-infection onwards (Fig. 5B). By contrast, dic and nklys gene expression was down-regulated at $1 \mathrm{~h}$ postinfection (Fig. 5C and D).

\section{4. $B$ and $T$ cell markers were up-regulated in the retina at gene level by NNV infection}

We evaluated the transcription levels of gene markers for B lymphocytes (ighm) and T lymphocytes (tcrb), as well as the most important markers for CTL ( $c d 8 a$ ) and helper ( $c d 4)$ T cell subpopulations (Fig. 6, Supplementary table S1). The transcription of ighm was significantly higher in the infected group after 1, 72 and $144 \mathrm{~h}$ of viral infection than in the controls (Fig. 6A). In the case of T cells, tcrb gene expression was up-regulated from $72 \mathrm{~h}$ post-infection onwards (Fig. 6B), reflecting an influx of $\mathrm{T}$ cells. Among them, major markers for cytotoxic (cd8a; Fig. 6C) and helper (cd4; Fig. 6D) T cells resulted increased by NNV infection, suggesting that both cell types were recruited to the infection site. $c d 4$ mRNA was down-regulated $1 \mathrm{~h}$ after NNV infection but upregulated after 72 and $144 \mathrm{~h}$ whilst $c d 8 a$ was up-regulated from $24 \mathrm{~h}$ onwards.

\subsection{NNV infection induced the transcription of genes related to the CMC}

To ascertain whether NNV infection affects the CMC, the expression pattern of the gzma, gzmb and prf mediators in the retina was studied (Fig. 7, Supplementary table S1). Nevertheless, gzma gene showed increased transcriptional levels at different time points compared with control group ( 1 and $144 \mathrm{~h}$ post-infection) but was down-regulated $24 \mathrm{~h}$ after infection (Fig. 7A). The transcription of gzmb (Fig. 7B) and prf (Fig. 7C) was down-regulated $1 \mathrm{~h}$ post-infection. By contrast, gzmb transcription in the retina was up-regulated $144 \mathrm{~h}$ after infection and $p r f$ 72 at $144 \mathrm{~h}$ after infection with NNV.

\section{Discussion}

Although studies of the fish immune response to NNV have increased in recent years, they have only focused on typical immune tissues such as the head-kidney and the main target tissue, the brain. This study is the first to report on NNV infection attained by eye injection and how the retina, also one of the main target tissues of NNV, responds to NNV replication and how the immune response is orchestrated within this tissue. Our findings suggest that NNV spreads through the optical centre, which in our study exhibited transcript levels of viral $c p$ and $r d r p$ from $1 \mathrm{~h}$ post-infection onwards, as in other fish species following intraperitoneal infection [16]. Our data also pointed to increasing transcript levels up to $72 \mathrm{~h}$ post-infection, demonstrating that NNV replicates in a very active manner in the fish retina. This great increase in viral RNA transcripts coincides with extensive localization of $\mathrm{CP}$ in all the retinal layers, with the possible exception of the pigment layer, where viral infection cannot be confirmed since layer pigmentation obscures the red-staining of viral particles, and the first region of the optical centre and the medullary region. However, the virus was detected in most of retina layers of the European sea bass, unlike observations made in other species where fish were infected intraperitoneally or bath-challenged $[15,16]$. Furthermore, the retina is a tissue where the virus actively replicates since the B2 protein was 

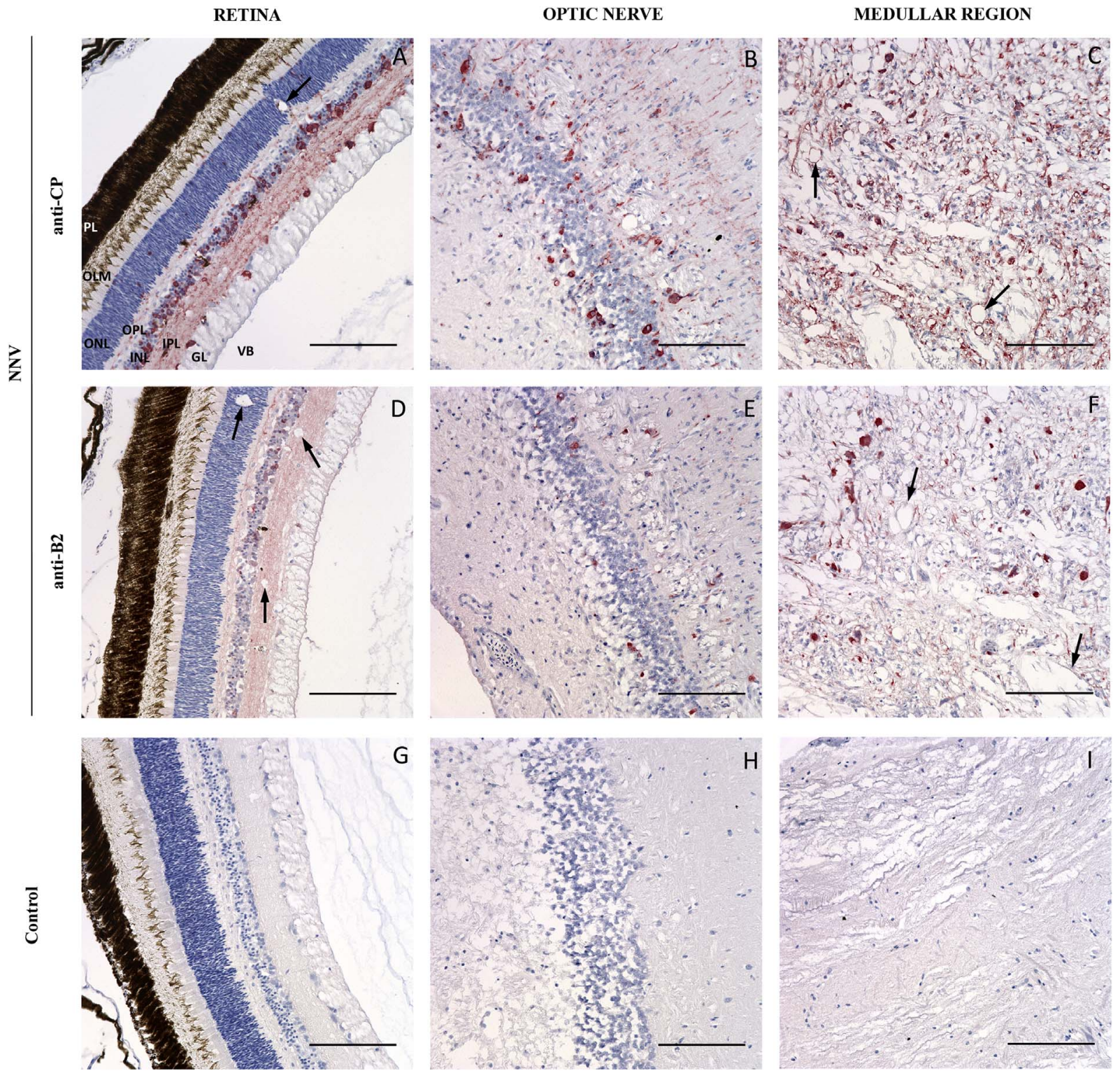

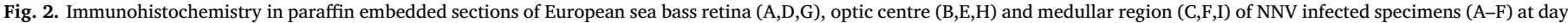

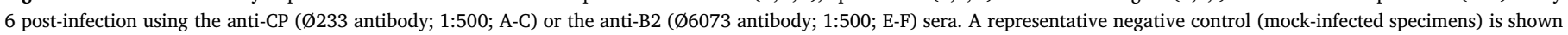

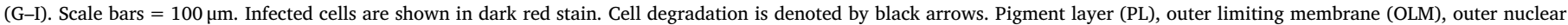

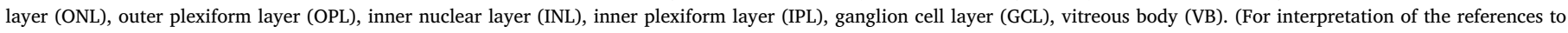
colour in this figure legend, the reader is referred to the Web version of this article.)

located in several cells of the outer nuclear layer, outer plexiform layer, inner nuclear layer, inner plexiform layer and ganglion layer, and also in the optical centre and medullary region, coinciding with the location of CP. Nevertheless, the outer limiting membrane is a layer in which, although infected, replication does not seem to take place as B2 protein was never detected. In reality, the outer limiting membrane is not a membrane per se, but a thin linear region comprising intercellular connections between photoreceptors and Müller cells and the complete cell is not represented [24]. This B2 protein mainly localizes on host mitochondria, which is needed for viral replication [25,26], suggesting that this area is poor in mitochondria and explaining the lack of anti-B2 staining. Concomitantly, the presence of CP particles in this limiting membrane could be due to the presence of free or cell membrane-attached NNV. B2 protein is expressed only in newly infected specimens and seems to be essential for viral replication and the high-level accumulation of viral RNA1 in the cells strongly antagonizes the host siRNA [8-10]. However, TEM analysis did not show any assembled virions in the retinal layers or optical centre regions, where typical signs of infections, including pycnosis and cell lysis, were evident from $24 \mathrm{~h}$ onwards. In contrast to our data, the appearance of this process coincides with the appearance of densely packed viral particles in the brain of other fish species [12,27]. Anyway, our data demonstrate the presence and active replication of NNV in the retina with morphological alterations in several layers, including the medullar region, which the virus colonizes extensively, leading to severe cell damage and tissue disintegration, and triggering the influx of immune cells in the microglia. These data agree with those found in Atlantic halibut, although in that case viral replication was not analysed [16]. The two main degenerative processes observed in NNV-infected brain were pycnosis and, more frequently, cell lysis, which is associated with tissue vacuolation [27]. Indeed, vacuolation in different retina layers has been described as being one of the main hallmarks of the histopathological changes observed during VNN disease outbreak [12-14]. In our study, the first signs of cell degradation were observed in the most external layers of 


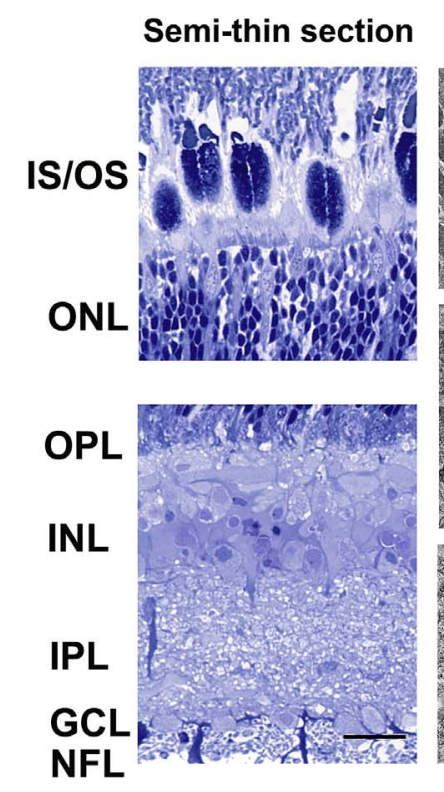

Injuries observed in electron micrographs
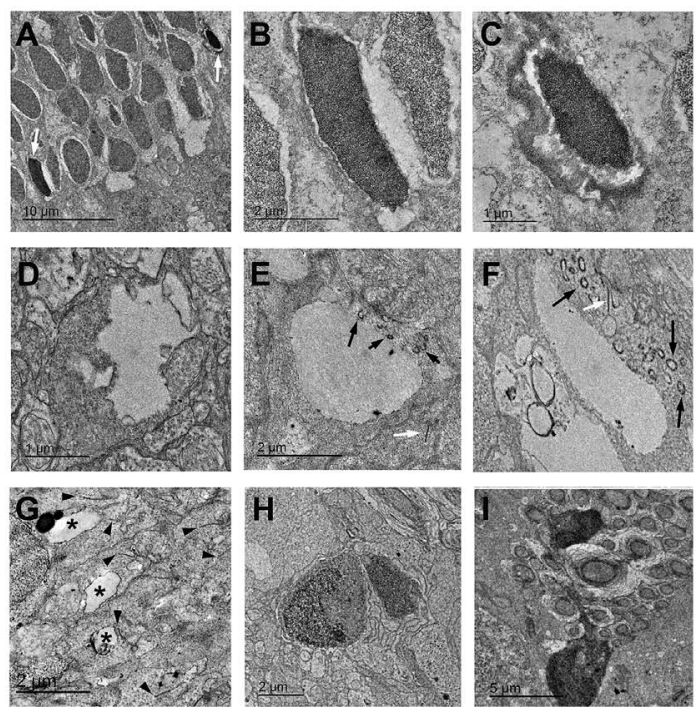

Fig. 3. Light and TEM micrographs from Dicentrarchus labrax retina. Light micrograph (left panel) show the retinal layers in semi-thin sections: layer of the inner and outer segments of photoreceptors (IS/ $\mathrm{OS}$ ), outer nuclear layer (ONL), outer plexiform layer (OPL), inner nuclear layer (INL), inner plexiform layer (IPL), ganglion cell layer (GCL), optic nerve fiber layer (NFL). Scale bars $=100 \mu \mathrm{m}$. The TEM micrographs (right panel) show the injuries produced after virus intravitreal injection. (A) Two scattered pyknotic nuclei (white arrows) in the ONL from infected fish $24 \mathrm{~h}$ after infection. (B and C) Images from the preceding micrograph to higher magnifications. Note the greater density and homogeneity of chromatin. (D, E and F) Three synaptic terminals of photoreceptors at the OPL. All have an extensive vacuolization $72 \mathrm{~h}$ after intravitreal injection. (D) Spherule from a rod photoreceptor. Synaptic vesicles and a mitochondrion can be observed. (E and F) Two cone pedicles intensely vacuolated. Note the presence of an electrodense material corresponding to typical spinules (black arrows) and some synaptic ribbons (white arrows). (G) In OPL photoreceptor synaptic terminals abundant synaptic ribbons are present (black arrowhead) and appear scarcely vacuolated (asterisk). Vacuolization was dramatically reduced seven days after injection. (H) Thin section from IPL showing dark microglial cells, infiltrating the neuropile seven days after injection. (I) NFL observed seven days after intravitreal injection.

\section{Type I IFN}
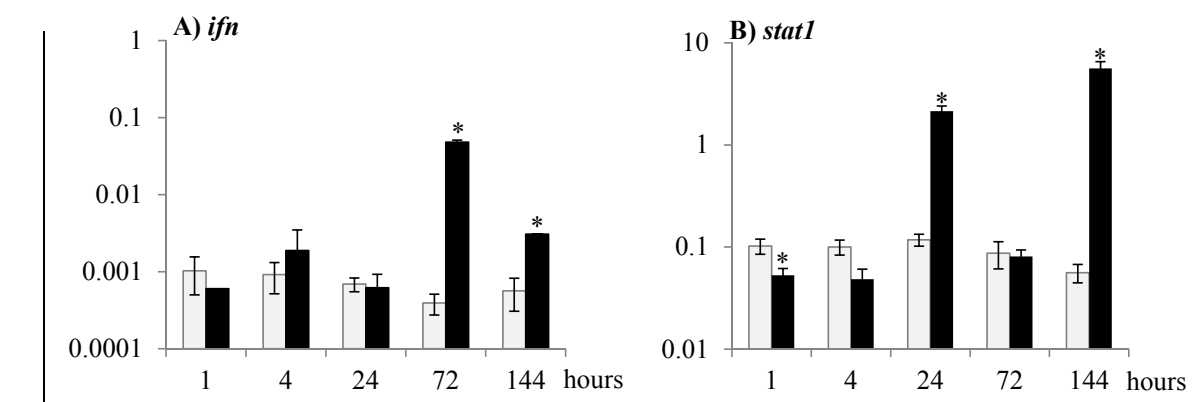

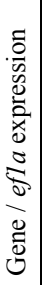

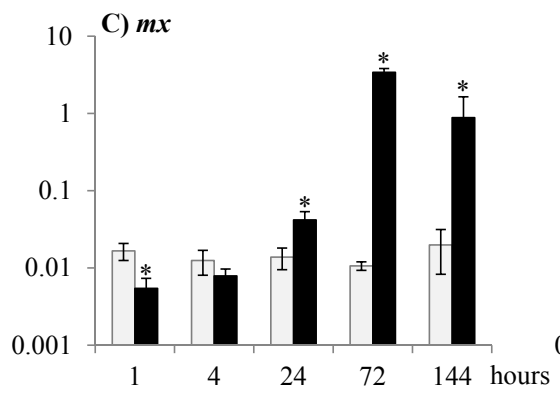

Type II IFN
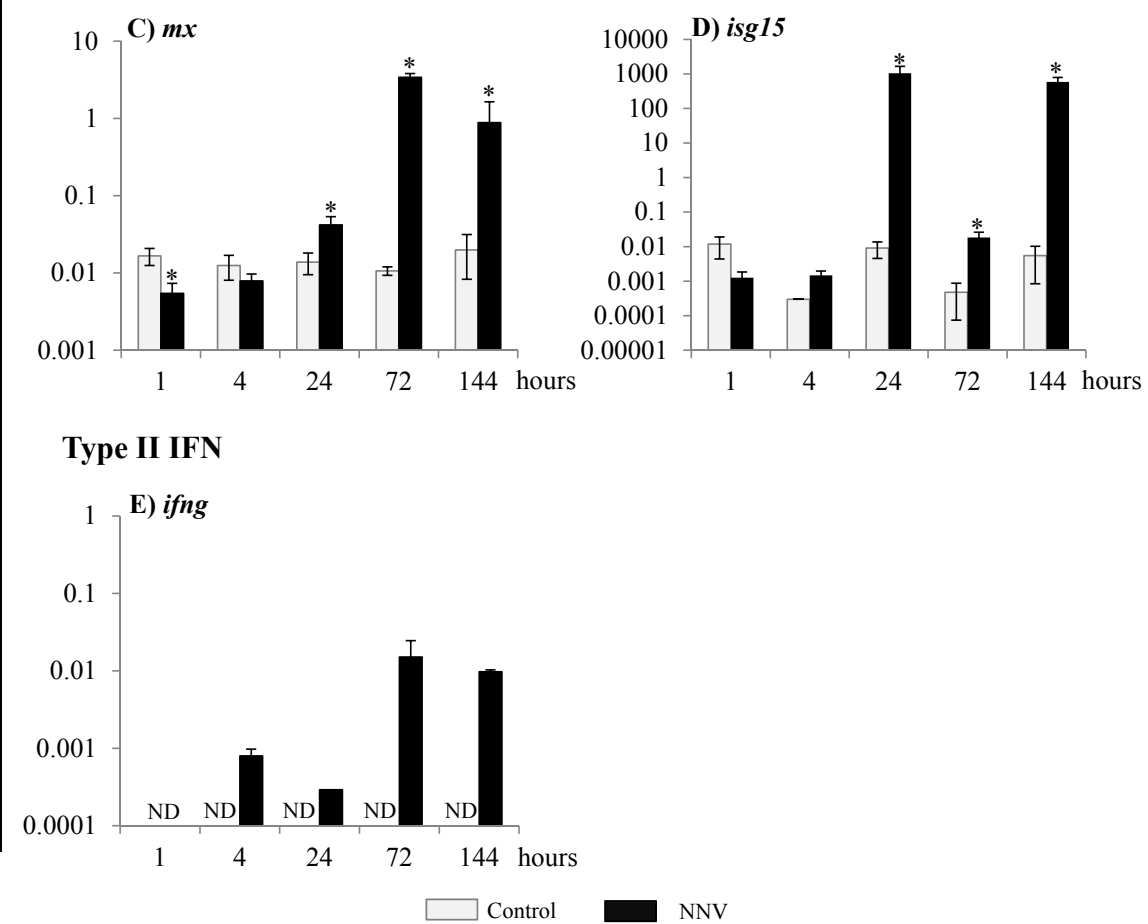

Fig. 4. NNV infection up-regulates the expression of type I and type II IFN genes. Transcription of ifn (A), stat1 (B), $m x$ (C), isg15 (D) and ifng (E) was studied in European sea bass retina $1,4,24,72$ and $144 \mathrm{~h}$ after intravitreal infection. Data represent the mean \pm SEM $(n=6$ fish retina/group and time). Asterisks represent statistical differences between control and infected (NNV) groups according to tStudent test. The significance level (P) was fixed at 0.05 . ND, non-detected. 

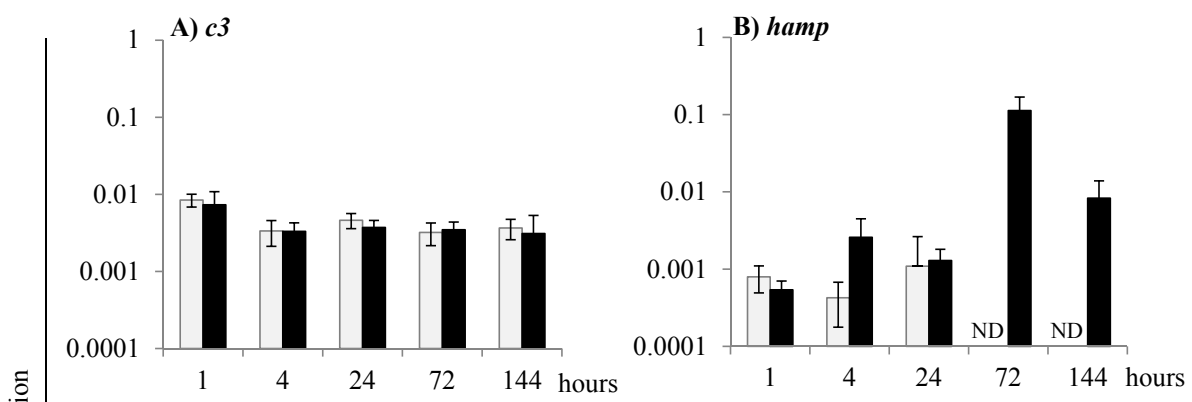

Fig. 5. NNV infection scarcely alters the AMP response in European sea bass retina. The gene expression of $c 3$ (A), hamp (B), dic (C) and nklys (D) was studied 1, 4, 24, 72 and $144 \mathrm{~h}$ after intravitreal infection with NNV. Data represent the mean \pm SEM ( $n=6 /$ group and time). Asterisks represent statistical differences between control and infected (NNV) groups according to the t-Student test. Significance level (P) was fixed at 0.05. ND, non-detected.
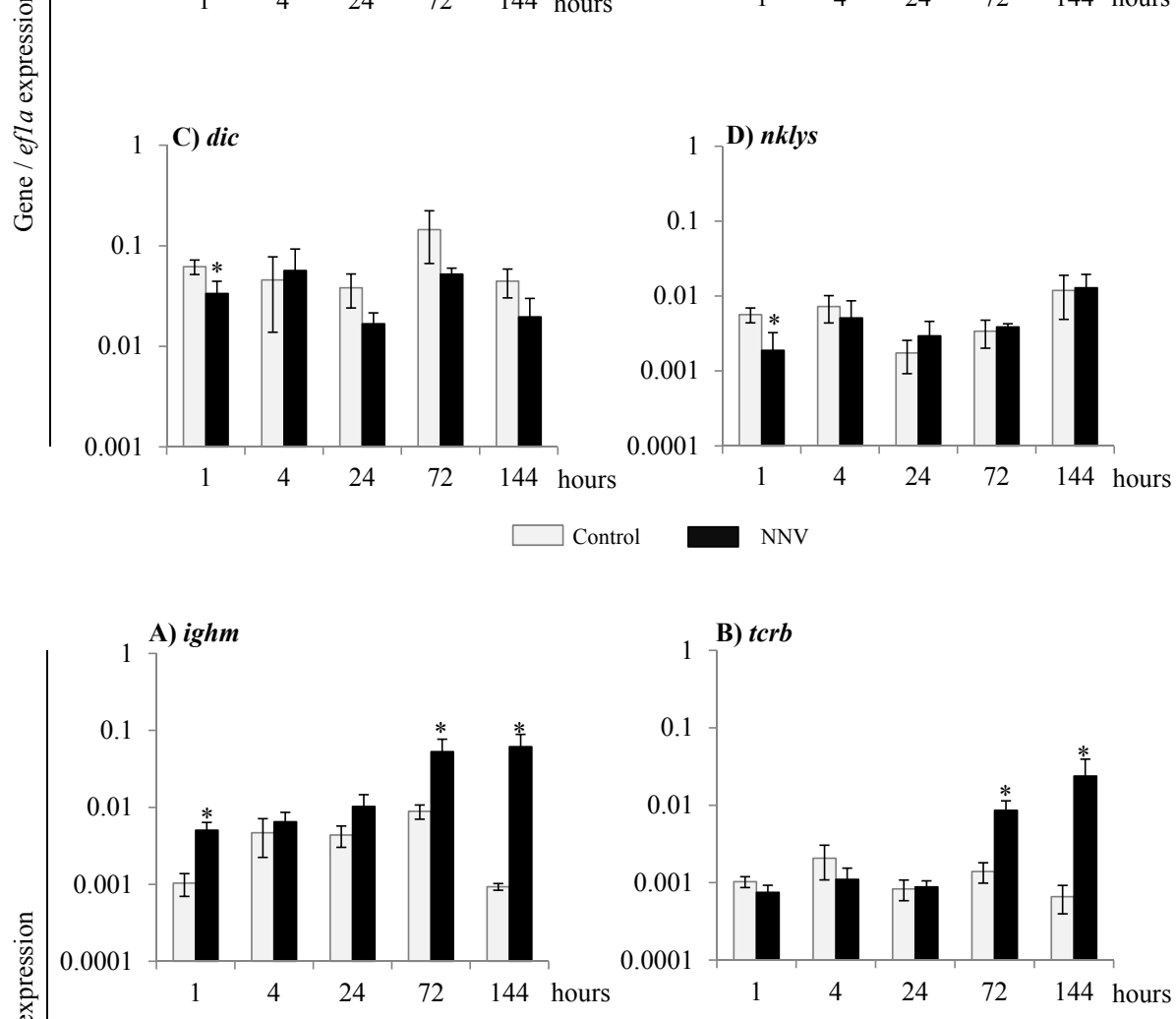

Fig. 6. NNV infection induced the gene expression of B and $\mathrm{T}$ lymphocyte markers. The gene expression of ighm (A; B cell), tcrb (B; T cell), cd8a (C; cytotoxic T lymphocytes) and cd4 (D; helper T lymphocytes) was studied 1, 4, 24, 72 and $144 \mathrm{~h}$ after intravitreal infection with NNV. Data represent the mean \pm SEM ( $n=6 /$ group and time). Asterisks represent statistical differences between control and infected (NNV) groups according to the t-Student test. Significance level (P) was fixed at 0.05 .

the retina - the outer nuclear and plexiform layers, in which pycnotic cells were present. As infection progressed, typical signs of infection reached the deeper layers of the tissue, where common cell degradation processes such as hydropic degeneration and vacuolization were evident, reaching the inner plexiform layer 3 days post-infection. Six days after infection, alterations in the microglia were evident, and disrupted myelin sheaths appeared, affecting the retina-brain connection [28], concomitantly with a diffuse vacuolation in the inner and outer plexiform layers and the presence of viral $\mathrm{CP}$ and B2 proteins in the optic nerve and the medulla regions. Since the optic nerve and retina suffered great degradation following NNV intravitreal infection, it is tempting to speculate that the main retina function - vision - is negatively affected in European sea bass as in other fish species showing similar changes in retinal structures [29].

Retina is an immune-privileged tissue. In mammals, retina immunity depends on an array of cells, including the retinal pigmented epithelial cells, resident macrophage/dendritic cells, as well as $\mathrm{T}$ (both CTLs, helper and regulatory) and B cells, which mediate, coordinate and execute the innate and/or adaptive immune responses [30-32]. However, this has not been confirmed in fish. In acute NNV infections in susceptible fish species, the immune response seems to be modulated in order to facilitate viral persistence, making virus replication and spreading easier [33-36]. Thus, we observed the down-regulation of some innate immune genes (stat1, $m x$, dic, nklys, cd4, gzmb and prf) as 

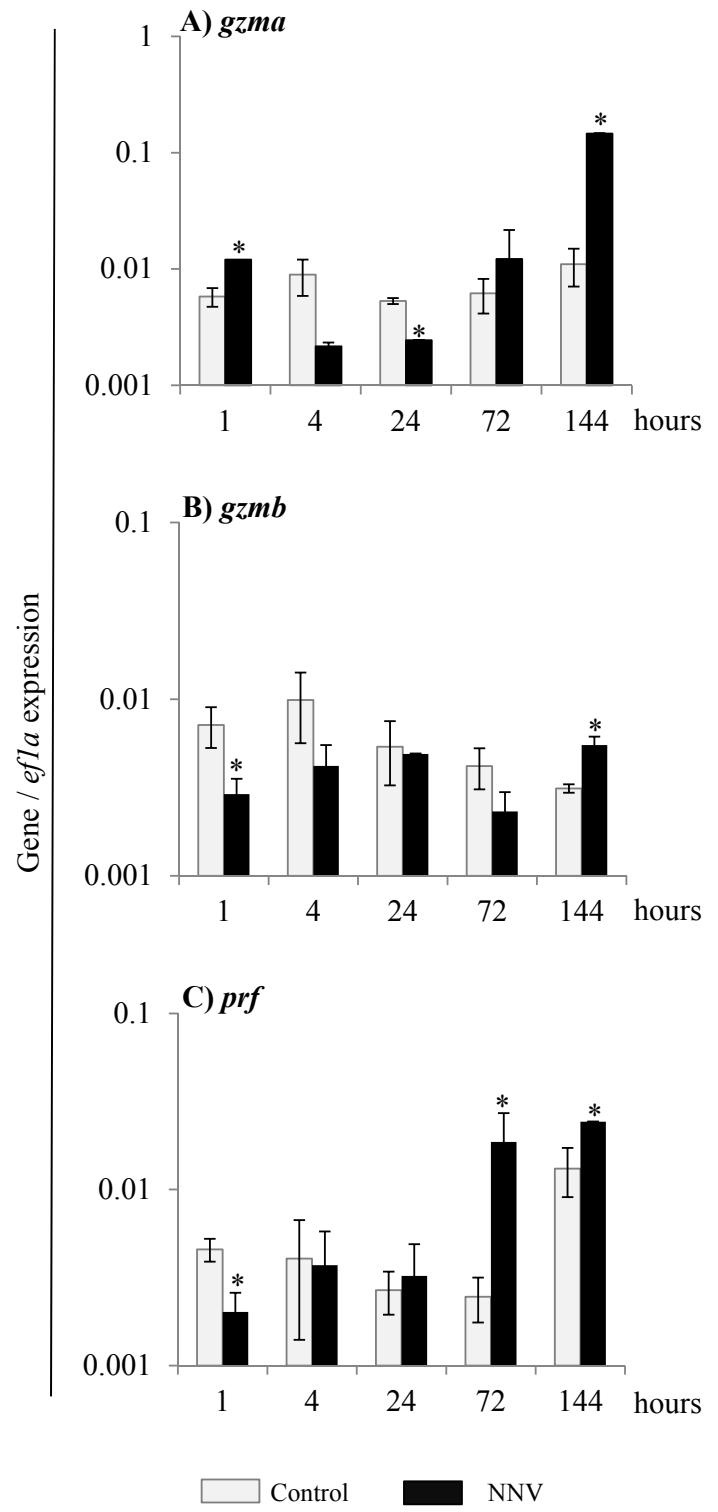

Fig. 7. NNV infection up-regulated the expression of CMC-related genes. Gene expression of gzma (A), gzmb (B) and prf (C) was studied 1, 4, 24, 72 and $144 \mathrm{~h}$ after intravitreal infection with NNV. Data represent the mean \pm SEM ( $n=6$ /group and time). Asterisks represent statistical differences between control and infected (NNV) groups according to the t-Student test. Significance level (P) was fixed at 0.05 .

early as $1 \mathrm{~h}$ post-infection. Previous studies have also described that NNV inhibits innate responses such as Mx protein in order to generate latent infections [37]. Our data extend this observation to innate immune responses, so that such immune suppression at the beginning of infection could facilitate viral replication, spread and dissemination. Later, the retina triggers the up-regulation of innate and adaptive immune response-related genes. Thus, from $24 \mathrm{~h}$, intravitreal infection triggered the up-regulation of ifn, stat1, $m x$ and isg15 gene expression, which showed the same pattern of expression, but to a greater extent, as in European sea bass brain $[36,38]$. The later up-regulation of type I IFN effectors highlights the relevance of this pathway in the defence against NNV in the retina, and it can be considered the most effective response against virus in fish $[39,40]$. Strikingly, $m x$, stat1 and isg15 transcription occurred earlier than ifn, pointing to the existence of an IFN-independent activation. Similar effects have already been documented in mammalian species, e.g. for human immunodeficiency virus (HIV), which induces a very rapid activation of Mx and ISGs independently of IFN and using STAT1 and IFN-regulatory factors 1 and 3
(IRF1 and IRF3) [41,42]. Following this hypothesis, we have already described the rapid up-regulation of $m x$ transcripts in the brain of NNVinfected sea bass after 1 day with no ifn being expressed; indeed, the down-regulation of most of the genes involved in the type I IFNpathway (MDA5, LGP2, MAVS, TRAF3, TANK, TBK1, IRF3, IRF7 and PKR) reinforced the notion of an IFN-independent pathway $[23,36]$. Interestingly, ifng gene expression was also up-regulated earlier than type I IFN genes and passed from being non-detected to clear evidence of expression from $4 \mathrm{~h}$ onwards. Although, as in mammals, IFN $\gamma$ is not always induced by viral infections [43], this cytokine shows potent antiviral activity dependent on type I IFN $[43,44,45]$, which correlates with our results in retina, as both type I and II IFN-related genes expression are induced by NNV. These data agree with results obtained in halibut, where ifng induction appears earlier in eye than in brain after NNV infection, coinciding with the first signs of vacuolation [16]. Furthermore, after vaccination with a CP-recombinant vaccine combined with oil adjuvant, the transcript levels of ifng were enhanced after NNV infection [46], highlighting the potential role of this molecule in fish immune response against NNV. Therefore, it looks as if the fish immune response against the virus might also be mediated by both IFNdependent and -independent mechanisms, a view that deserves further study. On the other hand, the antimicrobial response has been demonstrated as being of special relevance since some AMPs have strong antiviral activity [47-50]. Our data point to a weak response of AMPs in European sea bass retina since only the coding gene of hepcidin, hamp, was strongly up-regulated $72 \mathrm{~h}$ onwards. This up-regulation is of especial relevance taking into account that hepcidin from tilapia blocks NNV infection through virion agglutination [47]. As occurs in the retina, in other immune privileged tissues (brain and gonad), the hamp transcription is also up-regulated upon NNV infection [35]. Interestingly, other AMPs such as $c 3$ and dic, which are also up-regulated in gonad and brain, were not up-regulated in the retina, indicating the local tissue-specific regulation of this immune response.

As regards B cell immunity, our results showed increased levels of Blymphocyte (ighm) related gene, particularly at the end of the experiment. This would suggest an influx of B cells and probably the generation of adaptive humoral immunity though the exact time elapsing to the onset of this specific immunity remains undefined and needs to be confirmed at a functional level. However, in contrast to type I IFN and antimicrobial response related genes, ighm was up-regulated at $1 \mathrm{~h}$ post-infection and so it might play an important role in the defence against NNV in European sea bass retina from first moments after infection. This immunoglobulin transcription suggests a role for local natural antibodies, although their exact role in the response against viral infections remain unknown. For example, in NNV-infected sea bass [51], the expression of igm genes was up-regulated more than 100fold in the head-kidney $6 \mathrm{~h}$ after infection suggesting the proliferation, maturation and mobilization of immature B lymphocytes. Similarly, in gilthead seabream (Sparus aurata) infected with NNV, an increase in ighm transcription in the brain was observed $24 \mathrm{~h}$ post-infection, peaking after 30 days when the massive infiltration of $\mathrm{IgM}^{+}$-cells was evident [52]. Moreover, 3-6 days after infection there was a significant increase in IgM transcription and $\operatorname{IgM}^{+}$-cells in the brain and eye of Atlantic halibut, the increase being much higher in the retina, but the levels of specific IgM against NNV in plasma were not achieved until day 18 of infection [53]. All these studies describe how infection with NNV triggers the activation of mature B lymphocytes and/or the massive infiltration of $\mathrm{IgM}^{+}$B lymphocytes into the central nervous system, including the eye-chamber, leading to the generation of a potent adaptive humoral immunity [51-53], increasing the secretory-IgM mRNA [53]. However, the precise time of the generation, maturation and distribution of specific secreted anti-NNV IgM and anti-NNV IgMbearing B cells remains uncertain and deserves further evaluation.

Finally, regarding $\mathrm{T}$ cells immunity, our results showed the increased transcription of the T cell marker (tcrb), as well as of the major markers for the cytotoxic ( $c d 8 a$ ) and helper ( $c d 4) \mathrm{T}$ cell subpopulations, 
suggesting the formation of an adaptive cellular immunity in the retina of sea bass, which agrees with the $\mathrm{T}$ cell marker expression observed after NNV infection in other fish species [16,46,52]. Similarly, retina immunity has been also studied in rats infected with Borna disease virus (BDV), which affects the central nervous system, including the retina, and could represent a comparative model to NNV. BDV infection results in an increase in $\mathrm{T}$ cells, $\mathrm{CD}^{+}$cells as well as the protein levels of cytokines (IL1 $\alpha$, IL1 $\beta$, IL2, IL3, IL5, IL6, TNF $\alpha$, TNF $\beta$, IL4, IL10 and IFN $\gamma$ ) and chemokines (XCL1, CCL2, CCL4, CCL5 and CXCL10) in the rat retina [32] demonstrating the active role of adaptive cellular immunity. Something similar seems to be occurring in our study since NNV induced the transcription of cytokines/chemokines in the brain and head-kidney of seabream [52,54], in the brain and retina of Atlantic halibut $[16,46]$ and in the head-kidney of sea bass [51], pointing to the importance of $\mathrm{T}$ cells against NNV infections. In this respect, we also evaluated the expression of genes codifying for proteins important for CMC activity (cd8a, gzma, gzmb and prf), innate and/or adaptive. We previously demonstrated that sea bass infected with NNV manifest a rapid increase in innate CMC activity and the transcription of the non-specific cytotoxic cell receptor protein 1 (nccrp1) that mediates in this innate CMC activity [23], which agrees with the increased gzma transcription observed in this study. Interestingly, orange-spotted grouper (Epinephelus coioides) infected with NNV also showed increased CD8 mRNA transcripts, circulating $\mathrm{CD}^{+}{ }^{+}$-cells as well as specific CMC activity [55]. In addition, we also detected in the retina of infected sea bass an increase in the transcription of CMC-related genes encoding granzyme A and B and perforin, the most important mediators in the target cell lysis, which are mainly synthesized by non-specific cytotoxic cells (NCC) and cytotoxic T lymphocytes [56-59]. Although they have previously been documented as increasing at gene and/or functional levels in fish after viral infections [57,60,61], they have never been related to NNV. These transcripts are also concomitant with the expression of ifng gene, pointing to the probable activation of both the innate and specific CMC response, since cytotoxic cells are the main producers of IFN $\gamma$. Based on our transcriptional data and the scarce functional studies that exist, we predict an important role for the CMC response in the retina of European sea bass against NNV infections that merits further research.

\section{Conclusions}

In conclusion, intravitreal injection of $\mathrm{NNV}$ in the right eye of European sea bass led to infection of the retina, optical centre and microglia. NNV colonized the opposite retina extensively and actively replicated in both eyes. Moreover, extensive cell degradation (pycnosis and vacuolation) led to damage of myelin sheaths, probably disrupting the retinal function. Furthermore, the transcription of genes related to the IFN, CMC and B-lymphocyte responses was seen to increase in the retina of NNV-infected specimens, which might be of special relevance in the fight against NNV. Further studies are necessary to clarify whether the retina locally regulates the immune response after infection.

\section{Acknowledgments}

This work was supported by grants of the Ministerio de Economía y Competitividad and FEDER (AGL2013-43588-P), Fundacion Séneca (Grupo de Excelencia de la Region de Murcia 19883/GERM/15), Instituto Español de Oceanografía (NODAMED), and European Union Seventh Framework Programme for research, technological development and demonstration (KBBE-2013-07 single stage, GA 603121, DIVERSIFY). Yulema Valero thanks the Instituto Español de Ocenaografía for her PhD grant. Nodavirus strain and SSN-1 cells were kindly donated by Pilar Fernández Somalo (Laboratorio Central de Veterinaria de Algete, Ministerio de Medio Ambiente, Rural y Marino).

\section{Appendix A. Supplementary data}

Supplementary data related to this article can be found at http://dx. doi.org/10.1016/j.fsi.2018.01.034.

\section{References}

[1] B.L. Munday, J. Kwang, N. Moody, Betanodavirus infections of teleost fish: a review, J. Fish. Dis. 25 (2002) 127-142.

[2] F. Athanassopulou, C. Billinis, T. Prapas, Important disease conditions of new cultured species in intensive fresh water farms in Greece: first incidence of nodavirus infection in Acipenser sp. Dis. Aquat. Org. 60 (2004) 247-252.

[3] G. Bovo, A. Gustinelli, F. Quaglio, F. Gobbo, V. Panzarin, A. Fusaro, F. Mutinelli, M. Caffara, M.L. Fioravanti, Viral encephalopathy and retinopathy outbreak in freshwater fish farmed in Italy, Dis. Aquat. Org. 96 (2011) 45-54.

[4] FAO, The state of world fisheries and aquaculture, in: Food and Agriculture Organization of the United Nations (Ed.), Contributing to Food Security and Nutrition for All, 2016, p. 200.

[5] OIE, Viral encephalopaty and retinopathy, in: World Organization for Animal Health (Ed.), Manual of Diagnostic Test for Aquatic Animals, 2013, pp. 1-19.

[6] I. Sommerset, A.H. Nerland, Complete sequence of RNA1 and subgenomic RNA3 of Atlantic halibut nodavirus (AHNV), Dis. Aquat. Org. 58 (2004) 117-125.

[7] C. Tan, B. Huang, S.F. Chang, G.H. Ngoh, B. Munday, S.C. Chen, J. Kwang, Determination of the complete nucleotide sequences of RNA1 and RNA2 from greasy grouper (Epinephelus tauvina) nervous necrosis virus, Singapore strain, J. Gen. Virol. 82 (2001) 647-653.

[8] B.J. Fenner, R. Thiagarajan, H.K. Chua, J. Kwang, Betanodavirus B2 is an RNA interference antagonist that facilitates intracellular viral RNA accumulation, J. Virol. 80 (2006) 85-94.

[9] T. Iwamoto, K. Mise, A. Takeda, Y. Okinaka, K. Mori, M. Arimoto, T. Okuno, T. Nakai, Characterization of Striped jack nervous necrosis virus subgenomic RNA3 and biological activities of its encoded protein B2, J. Gen. Virol. 86 (2005) 2807-2816.

[10] K.B. Mézeth, S. Patel, H. Henriksen, A.M. Szilvay, A.H. Nerland, B2 protein from betanodavirus is expressed in recently infected but not in chronically infected fish, Dis. Aquat. Org. 83 (2009) 97-103.

[11] R. Aranguren, C. Tafalla, B. Novoa, A. Figueras, Experimental transmission of encephalopathy and retinopathy induced by nodavirus to sea bream, Sparus aurata L., using different infection models, J. Fish. Dis. 25 (2002) 317-324.

[12] J.S. Glazebrook, M.P. Heasman, S.W. de Beer, Picorna-like virus particles associated with mass mortalities in larval barramundi, Lates calcarifer Bloch, J. Fish. Dis. 13 (1990) 245-249.

[13] S. Grotmol, G.K. Totland, A. Kvellestad, K. Fjell, A.B. Olsen, Mass mortality of larval and juvenile hatchery-reared halibut (Hippoglossus hippoglossus L.) associated with the presence of virus-like particles in the central nervous system and retina, Bull. Eur. Assoc. Fish Pathol. 15 (1995) 176-180.

[14] B. Munday, J. Langdon, A. Hyatt, J. Humphrey, Mass mortality associated with a viral-induced vacuolating encephalopathy and retinopathy of larval and juvenile barramundi, Lates calcarifer Bloch, Aquaculture 103 (1992) 197-211.

[15] S. Grove, R. Johansen, B.H. Dannevig, L.J. Reitan, T. Ranheim, Experimental infection of Atlantic halibut Hippoglossus hippoglossus with nodavirus: tissue distribution and immune response, Dis. Aquat. Org. 53 (2003) 211-221.

[16] A.C. Øvergård, A.H. Nerland, I.U. Fiksdal, S. Patel, Atlantic halibut experimentally infected with nodavirus shows increased levels of T-cell marker and IFNgamma transcripts, Dev. Comp. Immunol. 37 (2012) 139-150.

[17] G. Breuil, O. Mouchel, C. Fauvel, J.F. Pepin, Sea bass Dicentrarchus labrax nervous necrosis virus isolates with distinct pathogenicity to sea bass larvae, Dis. Aquat. Org. 45 (2001) 25-31.

[18] A. LeBreton, L. Grisez, J. Sweetman, F. Ollevier, Viral nervous necrosis (VNN) associated with mass mortalities in cage-reared sea bass, Dicentrarchus labrax (L), J. Fish. Dis. 20 (1997) 145-151.

[19] B. López-Jimena, E. García-Rosado, K.D. Thompson, A. Adams, C. Infante, J.J. Borrego, C. Alonso Mdel, Distribution of red-spotted grouper nervous necrosis virus (RGNNV) antigens in nervous and non-nervous organs of European seabass (Dicentrarchus labrax) during the course of an experimental challenge, J. Vet. Sci. 13 (2012) 355-362.

[20] I. Benhar, A. London, M. Schwartz, The privileged immunity of immune privileged organs: the case of the eye, Front. Immunol. 3 (2012) 296.

[21] G. Frerichs, H.D. Rodger, Z. Peric, Cell culture isolation of piscine neuropathy nodavirus from juvenile sea bass, Dicentrarchus labrax, J. Gen. Virol. 77 (1996) 2067-2071.

[22] L.J. Reed, H. Müench, A simple method of estimating fifty per cent endpoints, Am. J. Epidemiol. 27 (1938) 493-497.

[23] E. Chaves-Pozo, F.A. Guardiola, J. Meseguer, M.Á. Esteban, A. Cuesta, Nodavirus infection induces a great innate cell-mediated cytotoxic activity in resistant, gilthead seabream, and susceptible, European sea bass, teleost fish, Fish Shellfish Immunol. 33 (2012) 1159-1166.

[24] D.L. Stenkamp, Neurogenesis in the Fish Retina, Int Rev Cytol, Academic Press, 2007, pp. 173-224.

[25] C.F. Low, B. Syarul Nataqain, H.Y. Chee, M.Z.H. Rozaini, M. Najiah, Betanodavirus: dissection of the viral life cycle, J. Fish. Dis. 40 (2017) 1489-1496.

[26] K.B. Mézeth, S. Nylund, H. Henriksen, S. Patel, A.H. Nerland, A.M. Szilvay, RNAdependent RNA polymerase from Atlantic halibut nodavirus contains two signals for localization to the mitochondria, Virus Res. 130 (2007) 43-52. 
[27] K. Yoshikoshi, K. Inoue, Viral nervous necrosis in hatchery-reared larvae and juveniles of Japanese parrotfish, Oplegnathus fasciatus (Temminck \& Schlegel), J. Fish. Dis. 13 (1990) 69-77.

[28] S. Nona, Regeneration in the Goldfish visual system, in: H. Kolb, E. Fernández, R. Nelson (Eds.), Webvision: the Organization of the Retina and Visual System, University of Utah Health Sciences Center, Salt Lake City (UT), 2005.

[29] S.C. Neuhauss, Behavioral genetic approaches to visual system development and function in zebrafish, J. Neurobiol. 54 (2003) 148-160.

[30] R. Zhou, R.R. Caspi, Ocular immune privilege, Biol Rep. 2 (2010) 3.

[31] V.L. Pérez, A.M. Saeed, Y. Tan, M. Urbieta, F. Cruz-Guilloty, The eye: a window to the soul of the immune system, J. Autoimmun. 45 (2013) 7-14.

[32] T. Stahl, C. Mohr, J. Kacza, C. Reimers, T. Pannicke, Characterization of the acute immune response in the retina of Borna disease virus infected Lewis rats, $\mathrm{J}$. Neuroimmunol. 137 (2003) 67-78.

[33] M.W. Lu, Y.M. Chao, T.C. Guo, N. Santi, O. Evensen, S.K. Kasani, J.R. Hong, J.L. Wu, The interferon response is involved in nervous necrosis virus acute and persistent infection in zebrafish infection model, Mol. Immunol. 45 (2008) 1146-1152.

[34] Y. Valero, M. Arizcun, M.A. Esteban, I. Bandín, J.G. Olveira, S. Patel, A. Cuesta, E. Chaves-Pozo, Nodavirus colonizes and replicates in the testis of gilthead seabream and European sea bass modulating its immune and reproductive functions, PLoS One 10 (2015) e0145131.

[35] Y. Valero, A. García-Alcázar, M.A. Esteban, A. Cuesta, E. Chaves-Pozo, Antimicrobial response is increased in the testis of European sea bass, but not in gilthead seabream, upon nodavirus infection, Fish Shellfish Immunol. 44 (2015) 203-213.

[36] Y. Valero, P. Morcillo, J. Meseguer, F. Buonocore, M.A. Esteban, E. Chaves-Pozo, A. Cuesta, Characterization of the interferon pathway in the teleost fish gonad against the vertically transmitted viral nervous necrosis virus, J. Gen. Virol. 96 (2015) 2176-2187.

[37] Y.C. Wu, S.C. Chi, Persistence of betanodavirus in Barramundi brain (BB) cell line involves the induction of Interferon response, Fish Shellfish Immunol. 21 (2006) $540-547$.

[38] L. Poisa-Beiro, S. Dios, A. Montes, R. Aranguren, A. Figueras, B. Novoa, Nodavirus increases the expression of Mx and inflammatory cytokines in fish brain, Mol. Immunol. 45 (2008) 218-225.

[39] B. Robertsen, The interferon system of teleost fish, Fish Shellfish Immunol. 20 (2006) 172-191.

[40] C.E. Samuel, Antiviral actions of interferons, Clin. Microbiol. Rev. 14 (2001) 778-809.

[41] L.M. Baca, P. Genis, D. Kalvakolanu, G. Sen, M.S. Meltzer, A. Zhou, R. Silverman, H.E. Gendelman, Regulation of interferon-alpha-inducible cellular genes in human immunodeficiency virus-infected monocytes, J. Leukoc. Biol. 55 (1994) 299-309.

[42] A.K.M. Furuya, H.J. Sharifi, C.M.C. Noronha, The curious case of type I IFN and MxA: tipping the immune balance in AIDS, Front. Immunol. 5 (2014) 419.

[43] D. Aggad, C. Stein, D. Sieger, M. Mazel, P. Boudinot, P. Herbomel, J.P. Levraud, G. Lutfalla, M. Leptin, In vivo analysis of Ifn-gamma1 and Ifn-gamma2 signaling in zebrafish, J. Immunol. 185 (2010) 6774-6782.

[44] P. Pereiro, G. Forn-Cuni, A. Figueras, B. Novoa, Pathogen-dependent role of turbot (Scophthalmus maximus) interferon-gamma, Fish Shellfish Immunol. 59 (2016) 25-35.

[45] B. Sun, I. Skjaeveland, T. Svingerud, J. Zou, J. Jorgensen, B. Robertsen, Antiviral activity of salmonid gamma interferon against infectious pancreatic necrosis virus and salmonid alphavirus and its dependency on type I interferon, J. Virol. 85 (2011) 9188-9198.
[46] A.C. Øvergård, S. Patel, O.J. Nostbakken, A.H. Nerland, Atlantic halibut (Hippoglossus hippoglossus L.) T-cell and cytokine response after vaccination and challenge with nodavirus, Vaccine 31 (2013) 2395-2402.

[47] T.J. Chia, Y.C. Wu, J.Y. Chen, S.C. Chi, Antimicrobial peptides (AMP) with antiviral activity against fish nodavirus, Fish Shellfish Immunol. 28 (2010) 434-439.

[48] Y.D. Wang, C.W. Kung, J.Y. Chen, Antiviral activity by fish antimicrobial peptides of epinecidin-1 and hepcidin 1-5 against nervous necrosis virus in medaka, Peptides 31 (2010) 1026-1033.

[49] M. Zhang, M. Li, L. Sun, NKLP27: a teleost NK-Lysin peptide that modulates immune response, induces degradation of bacterial DNA, and inhibits bacterial and viral infection, PLoS One 9 (2014) e106543.

[50] P. Pereiro, A. Romero, P. Díaz-Rosales, A. Figueras, B. Novoa, Nk-lysin, an antimicrobial peptide expressed in fish erythrocytes is involved in antiviral defense, Fish Shellfish Immunol. 53 (2016) 76.

[51] G. Scapigliati, F. Buonocore, E. Randelli, D. Casani, S. Meloni, G. Zarletti, M. Tiberi, D. Pietretti, I. Boschi, M. Manchado, B. Martin-Antonio, R. Jiménez-Cantizano, G. Bovo, F. Borghesan, N. Lorenzen, K. Einer-Jensen, S. Adams, K. Thompson, C. Alonso, J. Béjar, I. Cano, J.J. Borrego, M.C. Álvarez, Cellular and molecular immune responses of the sea bass (Dicentrarchus labrax) experimentally infected with betanodavirus, Fish Shellfish Immunol. 28 (2010) 303-311.

[52] A. López-Muñoz, M.P. Sepulcre, D. García-Moreno, I. Fuentes, J. Béjar, M. Manchado, M.C. Álvarez, J. Meseguer, V. Mulero, Viral nervous necrosis virus persistently replicates in the central nervous system of asymptomatic gilthead seabream and promotes a transient inflammatory response followed by the in filtration of IgM + B lymphocytes, Dev. Comp. Immunol. 37 (2012) 429-437.

[53] S. Grove, R. Johansen, L.J. Reitan, C.M. Press, B.H. Dannevig, Quantitative in vestigation of antigen and immune response in nervous and lymphoid tissues of Atlantic halibut (Hippoglossus hippoglossus) challenged with nodavirus, Fish Shellfish Immunol. 21 (2006) 525-539.

[54] A. Cuesta, S. Dios, A. Figueras, B. Novoa, M.A. Esteban, J. Meseguer, C. Tafalla, Identification of six novel CC chemokines in gilthead seabream (Sparus aurata) implicated in the antiviral immune response, Mol. Immunol. 47 (2010) 1235-1243.

[55] Y.T. Chang, Y.H. Kai, S.C. Chi, Y.L. Song, Cytotoxic CD8alpha + leucocytes have heterogeneous features in antigen recognition and class I MHC restriction in grouper, Fish Shellfish Immunol. 30 (2011) 1283-1293.

[56] K. Praveen, D.L. Evans, L. Jaso-Friedmann, Evidence for the existence of granzymelike serine proteases in teleost cytotoxic cells, J. Mol. Evol. 58 (2004) 449-459.

[57] R. Huang, S. Zhong, H. Liu, R. Kong, Y. Wang, W. Hu, Q. Guo, Identification and characterization of common carp (Cyprinus carpio L.) granzyme A/K, a cytotoxic cell granule-associated serine protease, Fish Shellfish Immunol. 29 (2010) 388-398.

[58] H. Toda, K. Araki, T. Morimoto, T. Nakanishi, Perforin-dependent cytotoxic mechanism in killing by CD8 positive T cells in ginbuna crucian carp, Carassius auratus langsdorfii, Dev. Comp. Immunol. 35 (2011) 88-93.

[59] H. Toda, T. Yabu, H. Shiba, T. Moritomo, T. Nakanishi, Evaluating antigen-specific cytotoxicity of CD8 + T cells in fish by granzyme B-like activity, Vet. Immunol. Immunopathol. 141 (2011) 168-172.

[60] M. Varela, G. Forn-Cuní, S. Dios, A. Figueras, B. Novoa, Proinflammatory caspase A activation and an antiviral state are induced by a zebrafish perforin after possible cellular and functional diversification from a myeloid ancestor, J. Innate Immun. 8 (2016) 43-56.

[61] M.C. Ordás, A. Cuesta, L. Mercado, N.C. Bols, C. Tafalla, Viral hemorrhagic septicaemia virus (VHSV) up-regulates the cytotoxic activity and the perforin/granzyme pathway in the rainbow trout RTS11 cell line, Fish Shellfish Immunol. 31 (2011) 252-259. 